ウイルス 44(1), 43-47, 1994

特集 植物ウイルス

\title{
7. 菌類で媒介される beet necrotic yellow vein virus
}

\author{
玉田 哲男 \\ (北海道立中央農業試験場・生物工学部)
}

\section{要旨}

Beet necrotic yellow vein virus (BNYVV) は, テンサイそう根病の病原ウイルスであり, 土壌菌 Polymyxa betaeによってうつされる。ウイルス粒子は 桿状で, $21 \mathrm{~K}$ 外被タンパク質と 1 本鎖 RNA から成る。 RNA $1 \sim 5$ の 5 種類の RNA がみつかっており, RNA- 1 と 2 は感染に必要であるが, RNA-3，4，5 はサテライト様である。RNA ゲノムはいずれも 5 '末 端がキャップ構造， 3 末端がポリ（A）配列である。 RNA-1には，237Kのタンパク質をコードする ORF が存在し, RNA 複製酵素と共通の配列が認められる。 RNA- 2 には，6 個の ORF が存在し，5’末端側には21 K外被タンパク質, つづいて $54 \mathrm{~K}$ タンパク質をコード する ORF が存在する。このタンパク質は, 外被タンパ

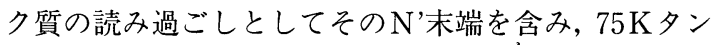
パク質として翻訳される。このタンパク質は, ウイル ス粒子の組立てと菌伝搬性に重要な役割を果たしてい る。さらに 3 '側の 3 個の ORF には，それぞれ $42 \mathrm{~K}, 13$ $\mathrm{K}, 15 \mathrm{~K}$ タンパク質がコードされ，これらはトリプロ ブロックジーンと呼ばれ，ウイルスの細胞間移行に関 与している。RNA-2の3 末端側には，システィン豊 富な $14 \mathrm{~K}$ タンパク質がコードされている。RNA- 3 に は, $25 \mathrm{~K}$ タンパク質の ORF が存在し,これは検定植物 （ツルナ）の黄色斑形成とテンサイのそう根症状の発 現に関わっている。 $31 \mathrm{~K}$ タンパク質をコードする

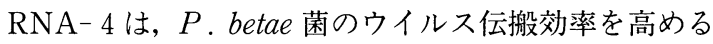
働きがある。以上, BNYVVに存在する 4 種の RNA

Beet necrotic yellow vein virus transmitted by the fungus Polymyxa betae

Tetsuo Tamada

Hokkaido Central Agricultural Experiment Station, Naganuma, Hokkaido 069-13

干069-13 北海道夕張郡長沼町東 6 線北 15 号
は，それぞれ機能分担しており，ウイルスが自然で病 気を起こし, 存続するために必須であると考えられる。

\section{はじめに}

Beet necrotic yellow vein virus (BNYVV，テンサ イえそ性葉脈黄化ウイルス) は，テンサイそう根病の 病原ウイルスであり, 土壤菌の 1 種 Polymyxa betae に よって伝搬される ${ }^{11)}$ 。BNYVVは, 実験室では汁液接 種によって感染させることができ，その寄生範囲は狭 く, 主としてアカザ科の植物に限られる。自然では, ウイルスは土壤中で $P$. betae の遊走子によって運ば れ，テンサイの根に感染し，そう根病をひき起こす。 ウイルス粒子は, 桿状でプラス鎖の RNA と $21 \mathrm{~K} の$ 外 被タンパク質から成る。ウイルス RNA は, 4 5 種の 分節ゲノムに分かれており, ウイルス粒子の長さは, RNA 種のサイズによって決められる ${ }^{17) 。 ~}$

BNYVV はウイルス粒子の形態, RNA の特性, 媒 介者, 伝染方法などから, 1987年の ICV では, Furovirus 群に含められているが, ゲノムの構造がタイプメン バーの soil-borne wheat mosaic virus と異なる点も あるため, possible member とされている8)。最近, こ のグループに属する potato mop-top virus や peanut clump virusについて, そのゲノムの一部の塩基配列 が決定されているが, グループ間の遺伝子構造にかな りの違いが認められている10) BNYVVは，他のウイ ルスとは異なった特徴をもつウイルスとして注目され ており,ここでは, BNYVVゲノムの構造と機能につ いて，最近得られた知見を紹介する。

\section{テンサイ龹う根病}

テンサイそう根病は, rhizomania と呼ばれ, 根に異 常を起こす病気である。1950年代イタリーで発生した のが最初であり, 長い間原因不明の土壤病とされてい たが, 1973年我々の研究によって,この病気が 
BNYVVの感染によって起こることが明らかにされ た ${ }^{11,14)}$ 。

BNYVVに感染すると, テンサイの根の細根が異常 に増加し, そう生するのが特徵である。激しい場合に は, 根は肥大せず, 奇形となり, 先端から主根にかけ てえ死を起こす。地上部の葉は退緑黄化する。ほ場で は, BNYVVはほとんど根に局在するが，まれに地上 部にウイルスが移行すると葉の脈が鮮明に黄化し，え そを伴うため，テンサイの「necrotic yellow vein」と いう名がつけられた ${ }^{14)}$ 。

北海道では，1965年ごろから発生が認められ，現在 では約 $20 \%$ 以上ほ場がそう根病に污染されてい る ${ }^{12)}$ 。外国では1950年代にイ夕リーで発生して以来, 1970年代ヨーロッパ全域に発生地域が拡大，1980年以 降，東欧，旧ソ連，中国，アメリカにおいても急速に 発生が拡大している。

そう根病は，典型的な土壤伝染性病害であり，一度 污染されたほ場から病原菌を除くことは極めて困難で ある。また被害が大きいため, 農業上最も恐ろしい病 気の一つとして，注目されている ${ }^{12)} 。$

\section{媒介菌 Polymyxa betae}

BNYVVはPolymyxa betae によって伝搬される。 $P$. betae は変形菌門 (Plasmodiophorales) のネコブ カビ科に属する完全な活物寄生菌である5)。この科に はSpongospora 属菌と Polymyxa 属菌があり，いずれ もウイルスの媒介者として知られている。Polymyxa 属 菌はさらにP. graminis と, $P$. betaeの 2 種類に分け られている。両者は形態的に同じであるが，寄主範囲 が異なり, 前者はイネ科植物, 後者はアカザ科の植物
に寄生する5)。

$P$. betaeの生活史は十分明らかにされていない。一 般に休眠胞子から放出された遊走子が宿主の細根の表 皮または表層細胞に侵入し，変形体を経て，遊走子の うまたは休眠胞子になる。遊走子のうからは多数の遊 走子が放出される。これらの遊走子はいずれも直径約 $5 \mu \mathrm{m}$, 長短 2 本のべん毛を有し, 洋なし形をしてい る。休眠胞子は数 10 個から数 100 個が接合してクラス夕 一を作り，この状態で土壤中で長期間生存できる。

BNYVVが $P$. betaeでうつされる場合，ウイルス は遊走子の内部に存在するが，菌体内では増殖しない とされている1。菌の生活史のどの過程で，どのように してウイルスを特異的に獲得し，伝搬されるかについ ては明らかでない。

\section{BNYVV の遺伝子構成}

BNYVVには，ゲノムのサイズの異なる 5 種の RNA が報告されており，サイズの大きい順に RNA1 〜 RNA- 5 と名付けられている8,17)。RNA-1 $\sim 4$ の 4 種は, ほ場分離株に常に存在し，発病とウイルスの 伝搬に必要である ${ }^{17)}$ 。RNA- 5 は今のところ日本の分 離株からのみ見つかっている。四に示すように， 5 種 の RNAのすべての全塩基配列が決定されている ${ }^{8)}$ 。 これらの RNA ゲノムは，いずれも5’末端がキャップ 構造, 3 ’末端がポリ (A) 配列である。 5 ’末端の 8 〜 塩基と 3 '末端の少なくとも70塩基に相同性が認めら れており，多分ウイルス RNAの複製開始域として重 要な役目を果たしていると推定される ${ }^{8)}$ 。

BNYVVゲノムの特徴は, RNA-1 と RNA- 2 がウ イルスの感染と増殖に必要であり, RNA-3，4，5 は
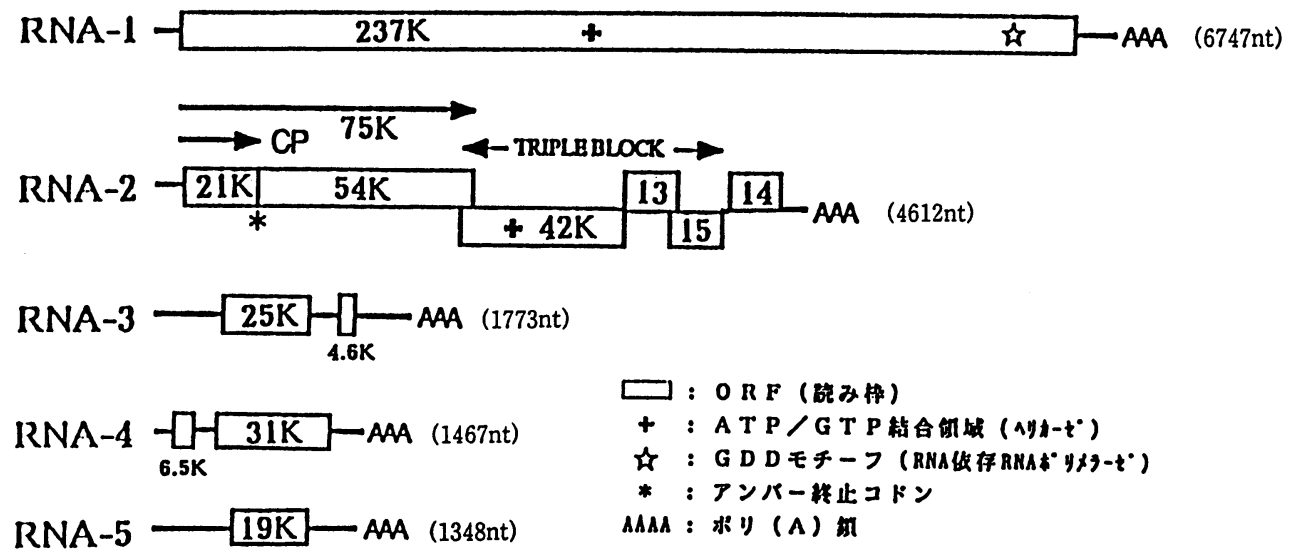

図 BNYVVの遺伝子地困 
サテライト様であり, ウイルスの感染には必要でない

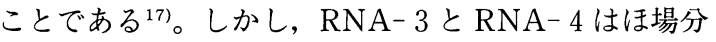
離株に常に存在することから, RNA-1 と RNA- 2 は すべての寄生に共通の “house keeping”機能をもつの に対して, RNA-3 と RNA-4 は自然感染の過程でよ り特異的な重要な役割を分担していると考えられ る ${ }^{8)}$ 。その詳細は後述する。

\section{BNYVV ゲノムの機能と遺伝子産物}

\section{1. 複製と $237 \mathrm{~K}$ タンパク質}

RNA- 1 （6,747塩基）には， 1 個の長いORF が存 在し, $237 \mathrm{~K} の$ タンパク質がコードされている (図) ${ }^{8)}$ 。 プロトプラストでは，RNA-1のみによってウイルス RNA が複製されることが証明されており， RNA-1 には複製のためのすべての情報が含まれていると考え られる8)。

$237 \mathrm{~K}$ タンパク質には, Sindbis-like supergroup の ウイルス感染に必要な非構造タンパク質にみられる領 域と相同性のある領域が 2 ヶ所存在する ${ }^{2)}$ 。一い, C 末端に近い位置の 200 残基で, RNA 依存 RNA ポリメ ラーゼに共通のアミノ酸配列，すなわち GDD 配列が 検出されており, 多分 core ポリメラーゼ機能をもつと 考えられている。他は, ORF のほぼ中央の260残基に GXXGXGKS/T 配列が存在する。これはATPまたは GTP 依存性 RNA またはRNAへリカーゼ活性をも つタンパク質と共通の配列である（図）。

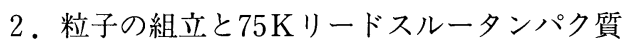

RNA- 2 （4,612塩基）には， 6 個の ORF が存在す る (図) ${ }^{8)}$ 。 5 '末端から最初の ORF 1 には, $21 \mathrm{~K}$ 外被 タンパク質, つづいて ORF 2 には, その外被タンパク 質シストロンからアンバー終止コドンとして読み過ご

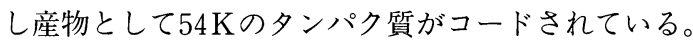
これは外被タンパク質の $\mathrm{N}^{\prime}$ 末端を含み, $75 \mathrm{~K}$ タンパク 質として翻訳される（75Kリードスルータンパク質と 呼ぶ)。このタンパク質は, $21 \mathrm{~K}$ 外被タンパク質と ともに, 感染細胞のどの分画からも多量に検出される7)。

Schmitt ら (1992) は，外被夕ンパク質とウイルス粒 子の再構成を知るため, 外被夕ンパク質遺伝子の領域 にいくつかの欠失を起こさせ， RNA-1 とともにプロ トプラストまたは植物に接種を行なった。その結果, 外被夕ンパク質遺伝子のどの変異株もウイルス粒子は 形成されなかったという ${ }^{9)}$ 。例えば，外被タンパク質の 1 ヶ所に点変異, 119番目のアルギニンをセリンに変え ただけでもウイルス粒子は形成されなかった。さらに 彼らは5 $4 \mathrm{~K}$ タンパク質もまた粒子の再構成に影響して
いる結果を示した。例えば外被夕ンパク質の終止コド ンより下流の350塩基内に109塩基の短い欠失を起こさ せた変異株は, ウイルスの再構成を強く阻害したとい j ${ }^{9)}$ 。

3. 細胞間移行とトリプルブロックタンパク質

RNA- 2 には, ORF 2 につづいて $42 \mathrm{~K}, 13 \mathrm{~K}$ よび $15 \mathrm{~K}$ のタン゚ク質をコードする 3 個の ORF が存在す る (図) ${ }^{8)}$ 。これら 3 個の遺伝子はトリプルブロックジ ーンと呼ばれ, 他の桿状ウイルス, potexviruses, carlaviruses および barley stripe mosaic virusにも存在 し，部分的に相同性が認められている6)。

BNYVV の $42 \mathrm{~K}$ と $13 \mathrm{~K}$ タンパク質はサブゲノミッ

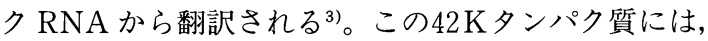
$237 \mathrm{~K}$ タンパク質のへリカーゼに共通に保存されてい るアミノ酸配列が見出されている。 $13 \mathrm{~K}$ と $15 \mathrm{~K}$ タンパ ク質は疎水性が高く, $42 \mathrm{~K}$ タンパク質とともに感染植 物の膜成分を含む画分から検出されている77。このト リプルブロックジーンの位置にいくつかの欠失を起こ させ, RNA-1 転写産物とともにプロトプラストと植 物へ接種を行った結果，すべての欠失変異株はプロト プラストで増殖したが，接種葉には目に見える病斑は 形成されなかったという ${ }^{3)}$ 。すなわち, これら 3 個の遺 伝子は, barley stripe mosaic virus や potexvirus に みられる遺伝子と同様, ウイルスの細胞間移行に関与 していると考えられる。

4. 病原性と $25 \mathrm{~K}$ タンパク質

BNYVVの野生株をツルナ（検定植物）に接種する と, 黄色斑, 退緑斑，え死斑など様々な病斑型が混在 して現われる11,17)。我々は,これらの病斑を単一病斑分 離によって増殖すると, それぞれ均一な安定した病徵 となり，その表現型と RNA 種との間に密接な関係が あることを示した17)。つまり RNA-3 を含む分離株 は, ツルナに黄色斑, テンサイに葉脈黄化症状, Beta macrocarpaに強い萎縮症状を示したことから，この RNA- 3 （1,773塩基）には病原性を左右する遺伝情報 が含まれていると考えた。

さらに我々は, BNYVVについて汁液による機械的 接種を繰り返すと, RNA-3 に欠失変異の生じること をみつけ，種々の RNA-3 欠失变異株を用いて病原性 の解析を行った。その結果, $25 \mathrm{~K}$ タンパク質の ORF 内 に欠失が生じると, ツルナ上の黄色斑がすべて退緑斑 に変わり，病原性が低下することを認めた。さらに Jupin ら (1992) はRNA-3 について人為的に変異株を 作成し，病斑形成を詳細に調べ，同様の結果を得てい る4)。また彼女らは，この実験でえ死斑を形成する領域 


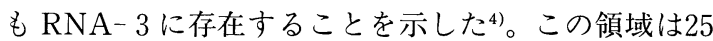
K ORF 内にあり, ORF-N と名ずけたが，興味あるこ とに全長の RNA- 3，つまり $25 \mathrm{~K}$ タンパク質が発現し ている時には，この遺伝子が発現せずサイレントであ るが，もしある特定の箇所に欠失が生じると ORF-N が活性化されると報告している4)。しかし，ツルナ接種 葉でのえ死斑形成について，我々はRNA-3 を含まな い分離株でもえ死斑が形成されることをしばしば観察 している。え死斑形成は細胞の過敏感死を意味してお り, 他の多くのウイルスと宿主との間で認められてい る。

先に述べたように, BNYVVはテンサイの根で特異 的に増殖し, 細根を増生さぜるのが特徵である。我々 は，25Kタンパク質を発現する正常株，その内部欠失 株およびRNA-3 を全く含まない分離株を各々保有 するP. betaeを作成し，テンサイに接種を行った。そ の結果， $25 \mathrm{~K}$ タンパク質を発現する正常なウイルス株 のみがそう根症状を示したのに対して，他の欠失変異 は全く病徵を示さず, 対照の無接種区と同じであった。 以上の結果は, $25 \mathrm{~K}$ タンパク質は, ツルナの黄色斑形 成と同様，根の細根を増加させる機能をもつと結論さ れる (未発表)。この $25 \mathrm{~K}$ タンパク質は，219個のアミ ノ酸から成り，システイン含量の多い領域があること から核酸結合タンパク質 (transcriptional activator) の機能をもつと考えられるが, どのような機構により 葉では黄色斑を形成し, 根では細根を増加させるのか, 今後の興味ある課題である。

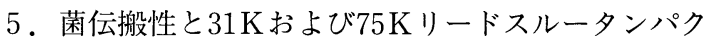
質

我々は，BNYVVの RNA-3 と RNA- 4 とが野外 分離株に常に存在することから，この RNA 種の菌伝 搬性における役割を調べた。その結果, RNA-4をもつ ウイルス分離株は，RNA-4 をもたない分離株より常 に効率よく菌によって伝搬されることをみつけた ${ }^{13)}$ 。 RNA-4（1,467塩基）には，31Kタンパクがコードさ れていること（図）から，このタンパク質が菌伝搬性 を向上させる働きがあると推定される。

しかしながら，RNA-4をもたないウイルス分離株 でも $P$. betaeによって伝搬されるため，本質的には RNA- 1 またはRNA- 2 に菌伝搬性に関与する遺伝 子が存在する可能性がある。そこで RNA-2 の欠失変 異株を用いて伝搬試験を行った。RNA-2 の欠失領域 は，54Kタンパク質をコードする ORF 2 のC'末端約 半分の部分で，1つは480塩基，他の 1 つは578塩基の 欠失が生じた変異株である。外被タンパク質は正常で
ある。これらの変異株を用いて $P$. betae による接種試 験を行ったところ, P. betae は，これらの RNA-2 変 異株を全くうつすことができなかった。すなわち， RNA- 2 にコードされている75Kリードスルータンパ ク質は，P. betaeのウイルス伝搬に必須であることが 証明された ${ }^{15)}$ 。

\section{6. $14 \mathrm{~K}$ タンパク質}

RNA-2の 3 末端にある ORF 6 には，14Kタンパ ク質がコードされている(図)。このタンパク質の特徵 はシステインリッチで $\mathrm{Zn}$-フィンガー配列をもち，in vitro では $\mathrm{Zn}{ }^{+}$にアフィニテーである ${ }^{8)}$ ここれらの性質 から核酸との結合タンパク質としての活性をもっと考 えられる。このタンパク質は, 感染した組織の細胞質 分画から容易に検出される77。14Kタンパク質の欠失 変異株は野生株に比べて, 局部病斑内のウイルス濃度 が極端に少なくなることを観察している3)。

\subsection{Kタンパク質}

日本の分離株に存在する RNA- 5 （1,348塩基）に は，19Kタンパク質がコードされている(図)。RNA5 は，テンサイに対して RNA-3 と異なった病原性を 示し, RNA-4 と同時に存在するとウイルスの増殖や 菌伝搬性を高める働きがあるが，このような機能と19 Kタンパク質の発現との関係はまだ明らかでない。

\section{おわりに}

テンサイそう根病の病原ウイルス (BNYVV) ゲノ ムの遺伝子産物とその機能について, 最近得られた知 見について述べた。ウイルスの機能として大切な感染 性, 病原性および伝搬性に関与する遺伝子の全体像が 明らかになったようにみえる。しかしながら，遺伝子 の解析が進むにつれて，さらに次のような疑問が生じ てきた。

(1)どのような仕組で $237 \mathrm{~K}$ タンパク質が複製酵素と して働くのか？ またどの領域が宿主域を決定してる のか？ (2)どのような機構によってトリプルブロック タンパク質がウイルスの細胞間移行に関与しているの か？ TMVなどでみられる $30 \mathrm{~K}$ タンパク質との関係 は？ (3) $25 \mathrm{~K}$ タンパク質が，なぜテンサイの細根を増 生させ，そう根病をひき起こすのか？ (4) $75 \mathrm{~K}$ と $31 \mathrm{~K}$ タンパク質が，どのような機構により菌体細胞と寄主 細胞に働きかけ，P. betae のウイルス伝搬性を制御し ているのか？このようにウイルスゲノムに対応した 宿主細胞側の遺伝子あるいは媒介菌側の遺伝子の応答 は，ほとんど明らかでない，それらを解決するために は，ここで述べたウイルスの遺伝子産物と宿主細胞の 
生化学的, 細胞化学的研究が必要である。

さらに, BNYVV はなぜ 4 種の分節ゲノムでなけれ ばならないのか。日本でみつかった RNA- 5 の役割は 何か。Furovirus 群や他のウイルスとの分子レベルで の比較もウイルスの分子進化と併せて, 今後の研究に 期待したい。

\section{文献}

1) Abe, H. and Tamada, T. (1986). Association of beet necrotic yellow vein virus with isolates of Polymyxa betae Keskin. Ann. Phytopathol. Soc. Japan, 52, 235-247.

2) Goldbach, R. and Wellink, J. (1988) . Evolution of plus-strand RNA viruses. Intervirology, 29, 260-267.

3) Gilmer, D., Bouzoubaa, S., Hehn, A., Guilley, H., Richards, K. and Jonard, G. (1992). Efficient cell-to-cell movement of beet necrotic yellow vein virus requires 3' proximal genes located on RNA 2. Virology, 189, 40-47.

4) Jupin, I., Guilley, H., Richards, K. E. and Jonard, G. (1992). Two proteins encoded by beet necrotic yellow vein virus RNA 3 influence symptom phenotype on leaves. EMBO J. 11, 479-488.

5) Keskin, B. (1964). Polymyxa betae n. sp., ein Parasite in den Würzeln von Beta vulgaris Tournefort, besonders während der Jugenden twickelung der Zuckerrübe. Archiv. Mikrobiol., 49, 348-374.

6) Morozov, S. Y., Dolja, V. V. and Atabekov, J. G. (1989). Probable reassortment of genomic elements among elongated RNAcontaining plant viruses. J. Mol. Evol. 29, 52 -62 .

7) Niesbach-Klösgen, U., Guilley, H., Jonard, G. and Richards, K. (1990). Immuno-detection in vivo of beet necrotic yellow vein virus encoded proteins. Virology, 178, 52-61.

8) Richards, K. E. and Tamada, T. (1992). Mapping funcitons on the multipartite genome of beet necrotic yellow vein virus. Ann. Rev . Phytopath., 30, 291-313.
9) Schmitt, C., Balmori, E. Jonard, G., Richards, K. E. and Guilley, H. (1992). In vitro mutangenesis of biologically active transcripts of beet necrotic yellow vein virus RNA 2: evidence that a domain of the $75-\mathrm{kDa}$ readthrough protein is important for efficient virus assembly. Proc. Natl. Acad. Sci. USA, 89, 5715-5719.

10) Shirako, Y. and Wilson, T. M. A. (1993). Complete nucleotide sequence and organization of the bipartite RNA genome of soil-borne wheat mosaic virus. Virology, 195, 16-32.

11) Tamada, T. (1975) . Beet necrotic yellow vein virus. CMI/AAB Descriptions of Plant Vir. uses, No.144.

12）玉田哲男. (1991)。テンサイそう根病ウイルス (BNYVV) 遺伝子の生物的機能, 植物防疫, 45 , 157-160.

13) Tamada, T. and Abe, H. (1989). Evidence that beet necrotic yellow vein virus RNA-4 is essential for efficient transmission by the fungus Polymyxa betae. J. Gen. Virol., 70, 33913398.

14) Tamada, T. and Baba, T. (1973). Beet necrotic yellow vein virus from rhizomania affected sugar beet in Japan. Ann. Phytopathol. Soc. Japan, 39, 325-332.

15) Tamada, T. and Kusume, T. (1991). Evidence that the $75 \mathrm{~K}$ readthrough protein of beet necrotic yellow vein virus RNA-2 is essential for transmission by the fungus Polymyxa betae. J. Gen. Virol., 72, 1497-1504.

16) Tamada, T., Saito, M., Kiguchi, T. and Kusume, T. (1990). Effect of isolates of beet necrotic yellow vein virus with different RNA components on the development of rhizomania symptoms. Proc. Symp. Int. Working Group on Plant Viruses with Fungal Vectors, 1st., ed. Koenig, R., pp 41-44.

17) Tamada, T., Shirako, Y., Abe, H., Saito, M., Kiguchi, T. and Harada T. (1989). Production and pathogenicity of isolates of beet necrotic yellow vein virus with different numbers of RNA components. J. Gen. Virol., 70, 3399-3409 